\title{
Pewarisan Sifat Ketahanan Cabai terhadap Infestasi Aphis gossypii Glover (Hemiptera: Aphididae)
}

\author{
Inheritance of Chili Pepper Resistance Against Infestation of Aphis gossypii Glover \\ (Hemiptera: Aphididae)
}

\author{
Ady Daryanto $^{1^{*}}$, Muhamad Syukur ${ }^{2}$, Awang Maharijaya ${ }^{2}$, dan Purnama Hidayat ${ }^{3}$
}

Diterima 05 Desember 2016/Disetujui 22 Februari 2017

\begin{abstract}
Aphis gossypii Glover is one of the major pests of chili pepper and can cause damage up to $65 \%$ when the population is not controlled. The objective of this research was to elucidate the genetic control of resistance inheritance character of chilli (Capsicum annuum L.) to $\underline{\text { A. gossypii. Set }}$ a population of six generations $(P 1, P 2, F 1, F 2, B C P 1, B C P 2$ was established from a cross between IPB C20 (resistant parent) with IPB C313 (susceptible parent). Choice test based experiments was applied with two aphids per leaf on a five-week-old seedlings. The results showed that based on number of individual aphids per plant, segregation of resistance and susceptibility characters in the F2 fitted to the normal distribution, indicated that resistance controlled by polygenic genes. Subsequently based of scaling test analysis, resistance characteristics based on the number of aphids per plant categorized overdominan against resistant parent and controlled by many genes. Genes

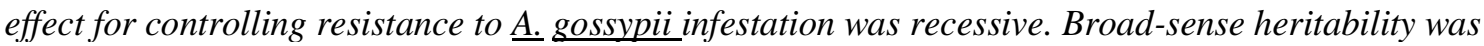
relatively large for the infestation of aphids per plant, aphids per leaf, and winged aphids while the narrow sense heritability relatively very low on the infestation aphids per plant and per leaf, indicated by the dominant variance was greater than additive variance.
\end{abstract}

Keywords: action genes, Capsicum annuum, dominant varience, heritability

\begin{abstract}
ABSTRAK
Kutudaun Aphis gossypii Glover adalah salah satu hama pengganggu penting dalam produksi tanaman cabai. Saat populasi kutudaun tidak terkendali dapat menyebabkan kerusakan tanaman cabai hingga $65 \%$. Tujuan penelitian ini adalah mempelajari kendali genetik pewarisan sifat ketahanan cabai (Capsicum annuиm L.) terhadap infestasi A. gossypii. Set populasi enam generasi $\left(\mathrm{P}_{1}, \mathrm{P}_{2}, \mathrm{~F}_{1}, \mathrm{~F}_{2}, \mathrm{BC}_{\mathrm{P} 1}, \mathrm{BC}_{\mathrm{P} 2}\right)$ dibentuk dari persilangan tetua $\mathrm{P}_{1}$ (IPB C20) dengan nilai infestasi rendah dan tetua $\mathrm{P}_{2}$ (IPB C313) yang bernilai infestasi tinggi. Metode skrining yang digunakan adalah choice test. Jumlah kutudaun yang diinfestasikan adalah dua ekor per daun pada bibit berumur lima minggu. Hasil penelitian menunjukkan bahwa karakter ketahanan cabai terhadap infestasi kutudaun berdasarkan jumlah $A$. gossypii per tanaman ialah tetua rentan overdominan terhadap tetua tahan dan dikendalikan oleh banyak gen. Gen-gen pengendali ketahanan terhadap infestasi A. gossypii adalah resesif. Nilai heritabilitas arti luas tergolong besar untuk infestasi kutudaun per tanaman, kutudaun per daun, dan kutudaun bersayap, sedangkan heritabilitas arti sempit tergolong sangat rendah pada infestasi kutudaun per tanaman dan per daun yang ditunjukkan oleh proposi ragam dominan lebih besar dibandingkan ragam aditif.
\end{abstract}

Kata kunci: aksi gen, Capsicum annuum, heritabilitas, ragam dominan

\footnotetext{
1* Program Studi Agroteknologi, Universitas Gunadarma.

Jl. Raya Margonda No. 100 Pondok Cina Depok 16424. Indonesia

${ }^{2}$ Departemen Agronomi dan Hortikultura, Fakultas Pertanian, Institut Pertanian Bogor

Jl. Meranti Kampus Darmaga, Bogor 16680 Indonesia.

${ }^{3}$ Departemen Proteksi Tanaman, Fakultas Pertanian, Institut Pertanian Bogor

J1. Kamper, Kampus IPB Darmaga, Bogor 16680 Indonesia.

Email: adydaryanto@yahoo.com (*penulis korespondensi)
} 


\section{PENDAHULUAN}

Kutudaun Aphis gossypii Glover merupakan hama penting pada pertanaman cabai di Indonesia. Kutudaun termasuk hama polifag yang memiliki banyak inang (Blackman dan Eastop, 2000), dalam kondisi tidak terkendali hama ini menyebabkan kerusakan mulai dari fase bibit hingga tanaman dewasa (Tilmon et al., 2011). Kerusakan yang terjadi antara lain klorosis, nekrosis, pengkerdilan, layu, aborsi bunga dan buah, serta distorsi dan difoliasi daun cabai (da Costa et al., 2011).

Informasi pewarisan sifat ketahanan cabai terhadap kutudaun masih terbatas dilaporkan dibandingkan dengan ketahanan cabai terhadap penyakit sehingga varietas cabai yang tahan terhadap infestasi hama kutudaun hingga saat ini belum banyak dikembangkan walaupun jenis hama ini terhitung penting pada wilayah dataran rendah yang lembab (Messelink et al., 2013) dan efektif sebagai vektor virus (Damayanti et al., 2010; da Costa et al., 2011). Menurut Yoon (2003), paling tidak terdapat tiga alasan kendala di dalam merakit tanaman tahan cekaman biotik seperti ketahanan terhadap hama kutudaun yaitu, (1) menentukan metode skrining, (2) ketersedian sumber gen ketahanan, dan (3) informasi pewarisan sifat yang beragam. Pengembangan varietas tahan hama memerlukan pengetahuan tidak hanya terhadap tanaman yang dimuliakan tetapi juga pengetahuan terhadap perilaku hama (pest behaviour) serta interaksi keduanya (Chahal dan Gosal, 2003). Berdasarkan hal tersebut, studi pewarisan sifat ketahanan cabai terhadap infestasi A. gossypii masih perlu dilakukan guna menentukan strategi dalam program pemuliaan yang efektif dan efisien untuk memperoleh varietas cabai berdaya hasil tinggi dan tahan infestasi A. gossypii.

Analisis pewarisan karakter kualitatif dan kuantitatif sangat penting dalam program pemuliaan tanaman. Analisis pewarisan suatu karakter populer dilakukan melalui analisis rata-rata generasi (generation means analysis) dari populasi bersegregasi hasil persilangan biparental (single cross) dengan melibatkan enam populasi (Poehlman, 1996). Analisis pewarisan sifat ketahanan terhadap kutudaun melalui populasi enam generasi dengan metode choice test telah dilaporkan pada beberapa jenis tanaman seperti mentimun (Liang et al., 2015), gandum (Turanli et al., 2012), melon (Boissot et al., 2010), kedelai (Mensah et al., 2008), dan kacang panjang (Kuswanto et al., 2007). Beberapa hasil penelitian memberikan kesimpulan kendali genetik yang berbeda-beda yaitu, monogenik hingga poligenik yang komplek (Dogimont $e t$ al., 2010). Menurut Liang et al. (2015) ketahanan mentimun terhadap A. gossypii dikendalikan oleh satu gen mayor aditifdominan dan poligenik aditif-dominan. Ketahanan melon terhadap A. gossypii adalah poligenik dengan empat aditif Quantitative Trait Loci (QTL) dan dua epistasis QTL melalui populasi RIls, recombinant inbreed lines (Boissot et al., 2010).

Ketahanan terhadap kutudaun pada jenis tanaman serta kutudaun yang berbeda juga telah dilaporkan. Ketahanan tanaman kedelai terhadap A. glycines dilaporkan dikendalikan oleh dua gen resesif yang berepistasis 15:1 (Mensha et al., 2008). Ketahanan gandum terhadap Diuraphis noxia dikendalikan oleh single gen-dominan (Turanli et al., 2012) sedangkan ketahanan kacang panjang terhadap A. craccivora dikendalikan oleh gen dominan rangkap dengan rasio 15 toleran : 1 peka, serta terdapat interaksi gen dominan $\mathrm{x}$ dominan pada evaluasi populasi F2 (Kuswanto et al., 2007).

Informasi genetik yang diperoleh dari analisis pewarisan sifat terdiri atas aksi gen, jumlah gen pengendali, keragaman genetik, heritabilitas serta informasi-informasi genetik lainnya (Arif et al., 2012; Mustafa et al., 2016). Informasi genetik tersebut sangat berguna dalam tahapan seleksi, sehingga seleksi diharapkan akan lebih efektif dan efisien. Penelitian ini bertujuan menduga beberapa parameter genetik yang berkaitan dengan pewarisan sifat ketahanan cabai terhadap infestasi A. gossypii.

\section{BAHAN DAN METODE}

Percobaan dilakukan pada bulan April 2014 sampai September 2015 di Laboratorium Genetika dan Pemuliaan Tanaman, Departemen Agronomi dan Hortikultura IPB. Percobaan ini merupakan bagian ke-2 dari rangkaian kegiatan penelitian yang meliputi beberapa percobaan yaitu: (1) Skrining ketahanan 
plasma nutfah cabai terhadap infestasi $A$. gossypii. (2) Studi pewarisan ketahanan cabai terhadap infestasi A. gossypii. (3) Analisis silang dialel untuk menentukan parameter genetik ketahanan cabai terhadap infestasi $A$. gossypii. Material genetik yang digunakan adalah enam populasi yaitu, IPB C20 $\left(\mathrm{P}_{1}\right)$ sebagai tetua dengan nilai infestasi A. gossypii yang rendah, IPB C313 $\left(\mathrm{P}_{2}\right)$ dengan nilai infestasi A. gossypii tinggi, dan turunan pertama $\left(\mathrm{F}_{1}\right)$ masing-masing 18 tanaman, lalu turunan kedua $\left(\mathrm{F}_{2}\right) 159$ tanaman serta populasi silang balik $\mathrm{P}_{1}$ dan $\mathrm{P}_{2}\left(\mathrm{BC}_{\mathrm{P} 1}\right.$ dan $\left.\mathrm{BC}_{\mathrm{P} 2}\right)$ masing-masing 28 dan 47 tanaman.

Bahan dan alat yang digunakan antara lain tray bersel 50, media tanam campuran: tanah, coco peat, dan pupuk kandang $(1: 1: 1)$, kotak serangga (insect proof box), ruangan bertemperatur $28 \pm 2{ }^{\circ} \mathrm{C}$, pencahayaan $16 \mathrm{jam}$, dan kelembaban udara (RH) $65 \pm 10 \%$ (Satar et al., 2008) serta kaca lup dan mikroskop binokuler untuk menghitung jumlah nimfa $A$. gossypii. Benih ditumbuhkan hingga menjadi bibit berdaun 4-6 atau berumur lima minggu setelah semai. Metode infestasi yang dilakukan adalah metode choice test dimana A. gossypii dibiarkan berpindah untuk makan dan bereproduksi secara bebas. Infestasi $A$. gossypii diberikan sebanyak dua ekor kutudaun tidak bersayap (Apterous aphids) per bibit dan dilakukan di dalam kotak berjaring kedap serangga sehingga membatasi penyebaran kutudaun ke inang lainnya. Evaluasi dilakukan pada hari ke-12 terhadap jumlah kutudaun pada tiap individu tanaman. Analisis data yang dilakukan adalah uji normalitas data, uji besaran nilai derajat dominansi serta jumlah gen-gen pengendali karakter, uji komponen ragam, uji kelayakan model genetik, dan uji nilai heritabilitas (Zhang et al., 2010; Arif et al., 2012).

\section{HASIL DAN PEMBAHASAN}

Pendugaan ketahanan tanaman dengan basis perhitungan jumlah koloni kutudaun yang diinfestasikan telah dilaporkan pada tanaman mentimun (Liang et al., 2015), chrysanthemum (He et al., 2010), kedelai (Mensah et al., 2008), dan kacang panjang (Kuswanto et al., 2007). Sedangkan penggunaan kutudaun tidak bersayap (Apterous aphids) berdasarkan pertimbangan kemudahan dalam penanganan saat melakukan infestasi telah dilakukan pula oleh Hesler dan Dashiell (2011) di keledai dan Doryanizadeh et al. (2017) pada tanaman mentimun.

Berdasarkan pengamatan data infestasi A. gossypii per tanaman, per daun, dan bersayap sebaran data dari populasi tetua cabai rentan $\left(\mathrm{P}_{2}\right.$ : IPB C313) berada pada nilai yang lebih tinggi dibandingkan sebaran nilai tetua cabai tahan ( $\mathrm{P}_{1}$ : IPB C20) (Gambar 1). Sebaran data populasi cabai $F_{1}$ pada ketiga data infestasi mengarah ke tetua cabai rentan. Hal tersebut mencerminkan bahwa gen pengendali ketahanan cabai terhadap infestasi A. gossypii bersifat resesif.

Sebaran populasi $F_{2}$ untuk ketiga data infestasi memiliki jangkauan yang lebih lebar dibandingkan populasi kedua tetua dan hibrida cabai IPB C20 x IPB C313. Jangkauan yang lebar disebabkan oleh ragam dan nilai tengah yang lebih tinggi dibandingkan populasi tetua serta hibrida. Hal tersebut mencerminkan bahwa segregasi yang terjadi terhadap infestasi A. gossypii pada populasi $\mathrm{F}_{2}$ hasil persilangan cabai IPB C20 x IPB C313 terjadi dengan baik atau maksimal.

\section{Uji Normalitas Frekuensi Populasi F $_{2}$}

Pendugaan awal untuk mengetahui banyaknya kendali gen pada karakter-karakter kuantitatif dilakukan dengan uji kenormalan data. Hasil sebaran data dan kurva kenormalan populasi $\mathrm{F}_{2}$ pada infestasi $A$. gossypii per tanaman dan per daun pada sifat ketahanan cabai terhadap hama kutudaun menunjukkan bahwa sebaran frekuensi $F_{2}$ ialah normal dengan nilai $\mathrm{P}>0.05$ (Gambar 1 A dan B). Sebaran data normal dan kontinu tersebut mengindikasikan bahwa infestasi $A$. gossypii per tanaman dan per daun pada cabai persilangan IPB C20 x IPB C313 dikendalikan oleh banyak gen (poligenik) atau gen-gen minor. Syukur et al. (2007) menyatakan pula bahwa wujud penampilan ketahanan yang dikendalikan secara poligenik berupa ragam kontinu dengan perubahan perbedaan ketahanan yang kecil.

Menurut Yunianti (2007), Populasi $F_{2}$ dapat bersegregasi dengan baik bila tetua yang digunakan memiliki perbedaannya yang jelas dan jauh pada karakter yang diujikan. Selain itu tersedianya tetua rentan dengan tingkat kerentanan yang tinggi (high susceptible) 
dapat meminimalkan perubahan gen yang dapat mempengaruhi rasio segregasi (Chahal dan Gosal, 2003). Genotipe IPB C313 telah terkonfirmasi tingkat kerentanannya terhadap infestasi A. gossypii berdasarkan percobaan antixenosis dan antibiosis (Daryanto, 2016).

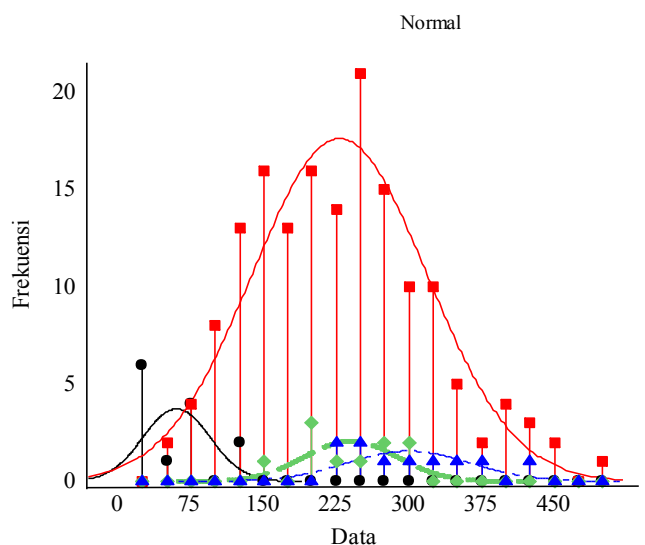

(A)

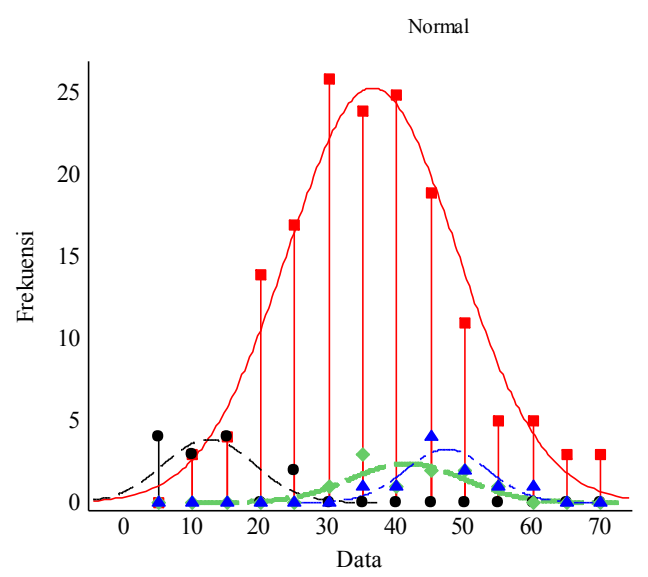

(B)

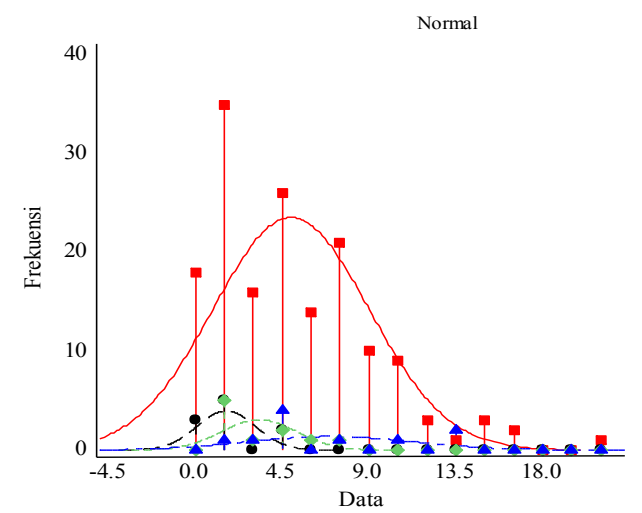

(C)

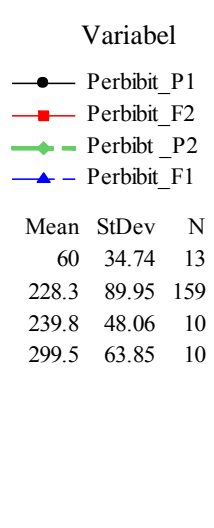

Variabel

$$
\begin{array}{rrr}
\longrightarrow- & \text { Perdaun_F2 } \\
-\bullet-- & \text { Perdaun_P1 } \\
-- \text { - Perdaun_P2 } & \text { Perdaun_F1 } \\
-\sim & & \\
\text { Mean } & \text { StDev } & \mathrm{N} \\
36.43 & 12.47 & 159 \\
12.35 & 6.671 & 13 \\
41.52 & 8.340 & 10 \\
47.34 & 6.083 & 10
\end{array}
$$

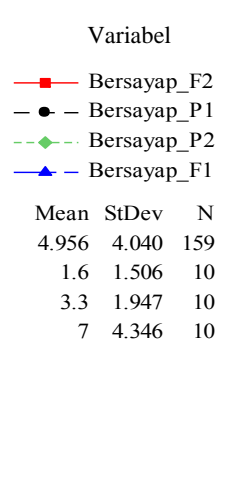

Gambar 1. A. Sebaran data infestasi A. gossypii per tanaman, B. Sebaran data infestasi A. gossypii per daun, C. Sebaran data infestasi A. gossypii bersayap pada populasi cabai $\mathrm{P}_{1}, \mathrm{P}_{2}, \mathrm{~F}_{1}$, dan $\mathrm{F}_{2}$. 
Infestasi A. gossypii bersayap menunjukkan pola penyebaran yang tidak normal, nilai $\mathrm{P}<0.05$ (Gambar 1C) dan memiliki nilai skewness 1.03 serta kurtosis 1.24. Menurut Roy (2000) sebaran data tidak normal dengan nilai skewness positif mencerminkan karakter tersebut dikendalikan oleh aksi gen aditif dengan pengaruh epistasis komplementer, sedangkan karakter dengan pola sebaran data tidak normal dan nilai skewness negatif mencerminkan adanya kendali gen aditif dengan pengaruh epistasis duplikat. Berdasarkan informasi tersebut maka dapat dinyatakan bahwa karakter infestasi $A$. gossypii bersayap dipengaruhi oleh aksi gen epistasis komplementer.

\section{Derajat Dominansi dan Jumlah Gen Pengendali}

Pendugaan derajat dominansi dilakukan melalui pendugaan potensi rasio $\left(h_{p}\right)$ dari nilai tengah tetua $\mathrm{P}_{1}, \mathrm{P}_{2}$, dan $\mathrm{F}_{1}$ menggunakan perhitungan yang diterangkan oleh Petr dan Frey (1966). Nilai potensi rasio negatif (Tabel 1) menggambarkan bahwa rata-rata nilai tengah infestasi kutudaun pada populasi $\mathrm{F}_{1}$ berada lebih tinggi dari nilai tengah tetua rentan. Hal ini mencerminkan preferensi kutudaun pada tetua rentan overdominan terhadap infestasi kutudaun di tetua tahan, dengan kata lain sifat ketahanan cabai terhadap A. gossypii dikendalikan oleh gen-gen resesif.

Ketahanan jagung terhadap kutudaun Rhopalosiphum maidis Fitch dikendalikan oleh gen resesif (So et al., 2010), dan ketahanan kedelai terhadap A. glycines dikendalikan pula oleh dua gen resesif yang berepistasis (Mensha et al., 2008). Ketahanan cabai terhadap beberapa penyakit dilaporkan dikendalikan oleh gen-gen resesif seperti ketahanan terhadap antraknosa yang dikendalikan oleh gen resesif parsial (Syukur et al., 2007).
Berdasarkan jumlah faktor efektif $(\mathrm{N})$ minimal terdapat satu kelompok gen-gen minor yang mengendalikan ketiga karakter tersebut (kutudaun per tanaman $0.71=1$, kutudaun per daun $0.86=1$, dan kutudaun bersayap $0.07=1$ ). Ketahanan yang dikendalikan gen-gen minor atau banyak gen dinilai lebih stabil akan tetapi sangat dipengaruhi oleh lingkungan. Chahal dan Gosal (2003) menyatakan bahwa model ketahanan terhadap serangga yang dikendalikan oleh poligen adalah tipe ketahanan horizontal (horizontal resistance). Posisi kendali gen-gen minor serta resesif pada infestasi A. gossypii terhadap ketahanan cabai di dalam penelitian ini memberi informasi bahwa gen-gen ketahanan tersebut masih belum terkumpul di dalam tetua tahan yang digunakan sehingga perlu dilakukan proses pemuliaan selanjutnya untuk mengumpulkan gen-gen ketahanan tersebut.

\section{Pendugaan Komponen Genetik}

Pendugaan komponen genetik melalui pengujian skala individu (scaling test) dilakukan dengan membandingkan nilai $\mathrm{t}$ hitung dengan t-tabel. Nilai duga parameter genetik uji skala individu karakter infestasi $A$. gossypii per tanaman, per daun, dan bersayap disajikan pada Tabel 2. Berdasarkan data tersebut model genetik yang sesuai untuk ketiga karakter uji adalah model aditifdominan $(\mathrm{m}[\mathrm{d}][\mathrm{h}])$ yang ditunjukkan oleh nilai t-hitung yang lebih kecil dari t-tabel. Hal ini mengindikasikan bahwa tidak terdapatnya efek epistasis pada preferensi kutudaun pada cabai hasil persilangan IPB C20 x IPB C313. Hill et al. (1988) menyatakan bila model aditifdominan sudah sesuai maka tidak diperlukan uji model skala gabungan (joint scaling test). Model genetik ketahanan cabai terhadap antraknosa dilaporkan mengikuti model aditifdominan (Syukur et al., 2007).

Tabel 1. Nilai potensi rasio dan jumlah faktor efektif sifat ketahanan cabai terhadap infestasi $A$. gossypii pada populasi IPB C20 x IPB C313

\begin{tabular}{lccc}
\hline \multirow{2}{*}{ Populasi } & \multicolumn{3}{c}{ Nilai Tengah Infestasi A. gossypii } \\
\cline { 2 - 4 } & Per Tanaman & Per Daun & Bersayap \\
\hline Potensi rasio (hp) & -1.70 & -1.42 & -5.35 \\
Aksi gen & Overdominan & Overdominan & Overdominan \\
Jumlah faktor efektif $(\mathrm{N})$ & 0.71 & 0.86 & 0.07 \\
\hline
\end{tabular}


Tabel 2. Nilai duga parameter genetik uji untuk skala individu infestasi A. gossypii per tanaman, per daun, dan bersayap pada cabai

\begin{tabular}{lccc}
\hline Parameter & $\begin{array}{c}\text { Kutudaun } \\
\text { Per Tanaman }\end{array}$ & $\begin{array}{c}\text { Kutudaun } \\
\text { Per Daun }\end{array}$ & $\begin{array}{c}\text { Kutudaun } \\
\text { Bersayap }\end{array}$ \\
\hline $\mathrm{m}$ & 228.30 & 36.44 & 4.96 \\
$\mathrm{D}$ & -70.66 & -7.45 & -1.12 \\
$\mathrm{H}$ & 48.83 & 1.85 & -1.18 \\
$\mathrm{C}$ & 5.51 & -4.60 & 0.92 \\
SE C & 52.89 & 6.46 & 3.13 \\
t-hitung & 0.10 & -0.71 & 0.30 \\
t-tabel & 1.96 & 1.96 & 1.96 \\
\hline
\end{tabular}

Keterangan: $\mathrm{C}=4 *$ rataan $\mathrm{F}_{2}-2 *$ rataan $\mathrm{F} 1-$ rataan $\mathrm{P}_{1}-$ rataan $\mathrm{P}_{2}$ (Roy, 2000); m: nilai tengah, D: nilai aditif, H: nilai dominansi, C: nilai interaksi gen, SE C: standard error C.

Tabel 3. Komponen ragam dan nilai heritabilitas sifat ketahanan cabai populasi persilangan IPB C20 x IPB C313 terhadap infestasi A. gossypii

\begin{tabular}{clrrr}
\hline \multirow{2}{*}{ No } & \multirow{2}{*}{ Parameter Genetik } & \multicolumn{3}{c}{ Infestasi Kutudaun } \\
\cline { 3 - 5 } & & Per Tanaman & Per Daun & Bersayap \\
\hline 1 & Ragam aditif $\left(\sigma^{2} \mathrm{D}\right)$ & -4168.62 & 22.23 & 23.34 \\
2 & Ragam dominan $\left(\sigma^{2} \mathrm{H}\right)$ & 38165.40 & 527.04 & 10.28 \\
3 & Ragam lingkungan $\left(\sigma^{2} \mathrm{E}\right)$ & 2533.22 & 50.13 & 831 \\
4 & Ragam fenotipe $\left(\sigma^{2} \mathrm{~F} 2\right)$ & 12074.60 & 193.01 & 22.56 \\
5 & Ragam BCP1 dan BCP2 & 24149.20 & 374.90 & 33.44 \\
6 & Heritabilitas arti luas $\left(\mathrm{h}^{2}{ }_{\text {bs }}\right)$ & $79 \%$ & $74 \%$ & $63 \%$ \\
7 & Heritabilitas arti sempit $\left(\mathrm{h}^{2}{ }_{\text {ns }}\right)$ & 0 & $6 \%$ & $52 \%$ \\
\hline
\end{tabular}

Heritabilitas merupakan refleksi pengaruh gen (genotipe) terhadap penampilan luar yang teramati (fenotipe). Nilai heritabilitas arti luas $\left(\mathrm{h}^{2}{ }_{\mathrm{bs}}\right)$ pada karakter infestasi kutudaun per tanaman, per daun, dan bersayap tergolong tinggi yaitu secara berurutan, 79\%, 74\%, dan 63\% (Tabel 3) akan tetapi nilai heritabilitas arti sempit $\left(\mathrm{h}^{2}{ }_{\mathrm{ns}}\right)$ karakter infestasi kutudaun per tanaman dan per daun tergolong sangat rendah yaitu, $0 \%$ dan 6\%. Nilai nol diperoleh karena ragam aditif yang negatif, sehingga dalam perhitungan selanjutnya dianggap bernilai nol atau tidak terdapat pengaruh aditif.

Para peneliti menyatakan pentingnya nilai aditif karena terwariskan dari tetua kepada keturunannya sehingga diharapkan memberikan kemajuan seleksi yang besar dan cepat terhadap suatu karakter (Chahal dan Gosal, 2003; Syukur et al., 2015). Nilai heritabilitas arti sempit di dalam penelitian ini jauh lebih rendah dibandingkan nilai heritabilitas arti luasnya untuk infestasi kutudaun per tanaman dan per daun. Hal ini mencerminkan proporsi ragam aditif jauh lebih kecil dibandingkan ragam dominan. Nilai tersebut tercermin pula dari hasil uji skala individu yang mana pengaruh dominansi lebih besar dibandingkan pengaruh aditif.

Heritabilitas arti sempit untuk infestasi kutudaun bersayap dalam kategori tinggi yaitu, $52 \%$ yang berarti proporsi ragam aditif lebih tinggi dibandingkan ragam dominan sehingga seleksi sifat ketahanan cabai terhadap infestasi kutudaun pada kutudaun bersayap dapat efektif dilakukan pada generasi akhir. Chahal dan Gosal (2003) menyatakan bahwa seleksi pada generasi lanjut sesuai untuk karakter yang dikendalikan oleh banyak gen dan ragam aditif yang tinggi. Sumber ketahanan perlu dipindahkan ke dalam galur elit dengan karakter hasil yang tinggi, maka rekombinan transgresif (convergent breeding) dan seleksi berulang dapat digunakan untuk pemuliaan dengan kendali gen-gen minor atau ketahanan horizontal (Niks et al., 2011; Syukur et al., 2015).

Pengaruh aditif yang rendah berimplikasi terhadap efektivitas seleksi. Berdasarkan data tersebut, tidak efektif melakukan seleksi terhadap sifat ketahanan cabai untuk infestasi kutudaun per tanaman 
dan kutudaun per daun oleh karena aksi gen aditif yang rendah. Hasil penelitian Laing $e t$ al. (2015) menunjukan aksi gen aditif yang tinggi pada sifat ketahanan mentimun terhadap infestrasi A. gossypii. Hal ini menunjukkan bahwa jenis tanaman atau varietas yang berbeda memungkinkan perbedaan dalam model pewarisan sifat ketahanan terhadap infestasi A. gossypii (Nashat dan Abdel-hafiz, 2008; Liang et al., 2015).

\section{KESIMPULAN}

Kesimpulan dari penelitian ini adalah karakter ketahanan berdasarkan jumlah kutudaun A. gossypii pada tanaman menunjukkan bahwa tetua rentan overdominan terhadap tetua tahan dan dikendalikan oleh banyak gen. Gen-gen pengendali ketahanan terhadap infestasi A. gossypii adalah resesif yang ditunjukkan oleh sebaran data populasi cabai $F_{1}$ pada ke tiga data infestasi mengarah ke tetua cabai rentan (IPB C313). Nilai heritabilitas arti luas tergolong besar untuk infestasi kutudaun per tanaman, kutudaun per daun, dan kutudaun bersayap, sedangkan heritabilitas arti sempit tergolong sangat rendah pada infestasi kutudaun per tanaman dan per daun yang ditunjukkan oleh proposi ragam dominan lebih besar dibandingkan ragam aditif.

\section{UCAPAN TERIMA KASIH}

Terima kasih kepada Direktorat Jenderal Pendidikan Tinggi (DIRJEN-DIKTI) atas dukungan dana penelitian dalam skema Hibah Kompetensi DIKTI tahun 2014 dan 2015 dengan No. kontrak 51/IT3.II/LT/2014 dan 083/SP2.H/PL/Ditlibamas/II/2015.

\section{DAFTAR PUSTAKA}

Arif, A.B., S. Sujiprihati, M. Syukur. 2012. Pendugaan parameter genetik pada beberapa karakter kuantitatif pada persilangan antara cabai besar dengan cabai keriting (Capsicum annuum L.). J. Agron. Indonesia. 40(2): 119-124.
Blackman, R.L., V.E. Eastop. 2000. Aphids on The World's Crops: Identification and Information Guide. 2nd Edition. John Wiley and Sons Ltd. England (GB).

Boissot, N., S. Thomas, N. Sauvion, C. Marchal, C. Pavis, C. Dogimont. 2010. Mapping and validation of QTLs for resistance to aphids and whiteflies in melon. Theor. Appl. Genet. 121: 9-20.

Chahal, G.S., S.S. Gosal. 2003. Principle and Procedures of Plant Breeding, Biotechnological and Conventional Approaches. Narosa Publishing House. New Delhi.

da Costa, J.G., E.V. Pires, M.A. Birkett, E. Bleicher. 2011. Differential preference of Capsicum spp. culivars by Aphis gossypii is conferred by variation in volatile semiochemistry. Euphytica. 177: 299-307.

Damayanti T.A, E. Muliarti, E. Sartiami. 2010. Efisiensi penularan virus mosaik bengkuang dengan Aphis craccivora Koch. dan $A$. gossypii Glover. Agrivigor. 3(2): 101-109.

Doryanizadeh N., S. Moharramipour, V. Hosseininaveh, M. Mehrabadi. 2017. Antixenotic resistance of eight Cucumis genotypes to melon aphid, Aphis gossypii (Hemiptera: Aphididae) and some associated plant traits. J. Crop Prot. 6(2): 207-214

Daryanto, A. 2016. Analisis genetik dan pewarisan sifat ketahanan cabai terhadap infestasi kutudaun A. gossypii, Aphis gossypii Glover (Hemiptera: Aphididae) [Tesis]. Institut Pertanian Bogor. Bogor.

Dogimont, C., A. Bendahmane, V. Chovelon, N. Boissot. 2010. Host plant to aphids in cultivated crops: genetic and molecular bases, and interactions with aphid populations. C. R. Biologies. 333: 566-573. 
He J.P., F.D. Chen, S.M. Chen., W.M. Fang. 2010. Aphid resistance of chrysantemem cultivars. Chin J. Ecol. 29: 1382-1386.

Hesler L.S., K.E. Dashiell. 2011. Antixenosis to the soybean aphid in soybean lines. J. Ento. 5: 39-44.

Hill, J., H.C. Becker, P.M.A. Tigerstedt. 1998. Quantitative and Ecological Aspects of Plant Breeding. Capman and Hall. London (UK).

Kuswanto, L. Soetopo, A. Affandhi, B. Waluyo. 2007. Pendugaan jumlah dan peran gen toleransi kacang panjang (Vigna sesquipedalis L. Fruwirth) terhadap hama kutudaun. Agrivita. 29(1): 1-9.

Liang, D., Q. Hu, Q. Xa, X. Qi, F. Zhou, X. Chen. 2015. Genetic inheritance analysis of melon aphid (Aphis gossypii Glover) resistance in cucumber (Cucumis sativus L.). Euphytica. 250: 361-367.

Mensah, C., C. DiFonzo, D. Wang. 2008. Inheritance of soybean aphid resistance in PI 567541B and PI567598B. Crop. Sci. 48: 1-5.

Messelink, G., C.J. Bloemhard, M. Sabelis, A. Janssen. 2013. Biological control of aphids in the presence of thrips and their enemies. BioControl. 58: 45-55.

Mustafa, M., M. Syukur, S.H. Sutjahjo, Sobir. 2016. Pewarisan Karakter Kualitatif dan Kuantitatif pada Hipokotil dan Kotiledon Tomat (Solanum lycopersicum L.) Silangan IPB T64 x IPB T3. J. Hort. Indonesia. 7(3): 155-164.

Nashat, A., Abdel-hafiz. 2008. Resistance of certain cucumber varieties to the melon aphid, Aphis gossypii (Glover). Zemdirbyste-Agri. 95: 293-297.

Niks, R.E., J.E. Parlevliet, P. Lindhout, Y. Bai. 2011. Breeding Crops with Resistance Disease and Pests. Wageningen Academic. Netherlands (NL).
Petr, F.C., K.J. Frey. 1966. Genotypic correlation, dominance, and heritability of quantitative characters in oat. Crop Sci. 6: 259-262.

Poehlman, J.M., D.A. Sleper. 1996. Breeding Field Crops. Low State University (US): Press. Low. 494 p.

Roy, D. 2000. Plant Breeding, Analysis, and Exploration of Variation. Narosa Publishing House. New Delhi.

Satar, S., U. Kersting, N. Uygun. 2008. Effect of temperature on population parameters of Aphis gossypii Glover and Myzus persicae (Sulzer) (Homoptera: Aphididae) on pepper. J. Plant. Dis. Protect. 2: 69-74.

So, Y-S., H.C. Ji, J.L. Brewbaker. 2010 Resistance to corn leaf aphid (Rhopalosiphum maidis Fitch) in tropical corn (Zea Mays L.). Euphytica. 172(3): 372-381.

Syukur, M., S. Sujiprihati, J. Koswara, Widodo. 2007. Pewarisan ketahanan cabai (Capsicum annuum L.) terhadap antraknosa yang disebabkan oleh Colletotrichum acutatum. Bul. Agron. 35(2): 112-117.

Syukur, M., S. Sujiprihati, R. Yunianti. 2015. Teknik Pemuliaan Tanaman Ed Revisi. Penebar Swadaya. Jakarta.

Tilmon, K.J., E.W. Hodgson, M.E. O'Neal, D.W. Ragsdale. 2011. Biology of the soybean aphid, Aphis glysines (Hemiptera: Aphididae) in the United States. J. Integ. Pest. Mngmt. 2(2):1-7.

Turanli, F., E. Ilker, F.E. Dogan, L. Askan, D. Istipliler. 2012. Inheritance of resistance to russian wheat aphid (Diuraphis noxia Kurdjumov) in bread wheat (Triticum aestivum L.). Turkish J. Field Crops. 17(2): 171-176.

Yoon, J.B. 2003. Identification of genetic resources, interspecific hybridization, and inheritance analysis for breeding pepper (Capsicum annuum) resistant to 
anthracnose [PhD thesis]. Seoul Natl University Seoul (KR).

Yunianti R. 2007. Analisis Genetik Pewarisan Sifat Ketahanan Cabai (Capsicum annuum L.) terhadap Penyakit Hawar Phytophthora dan Arah Pengembangan
Varietasnya [Disertasi]. Bogor (ID): Institut Pertanian Bogor.

Zhang, W., P. Liu, D. Hong, A. Huang, S. Li, Q. He, G. Yang. 2010. Inheritance of seeds per silique in Brassica napus L. using joint segregation analysis. Field Crop. Res. 116:58-67. 